\title{
FOCUSED REVIEW ON NUTRITIONAL STATUS OF PATIENTS WITH IMMUNOGLOBULIN LIGHT CHAIN AMYLOIDOSIS
}

\section{Short title: NUTRITIONAL STATUS IN AL AMYLOIDOSIS}

Shana Souza Grigoletti, MSc ${ }^{1}$; Priccila Zuchinali, $\mathrm{PhD}^{1}$; Émilie Lemieux-Blanchard, $\mathrm{MD}^{2}$;

Stéphanie Béchard, $\mathrm{NP}^{1,3}$; Bernard Lemieux, $\mathrm{MD}^{2}$;

Paula Aver Bretanha Ribeiro, $\mathrm{PhD}^{1}$; François Tournoux, $\mathrm{MD}, \mathrm{PhD}^{1,3}$

${ }^{1}$ Research Unit @CoeurLab, Centre de Recherche du Centre Hospitalier de l'Université de Montréal (CRCHUM)

${ }^{2}$ Hemato-Oncology division, Département d'Hématologie-Médecine Transfusionnelle du Centre Hospitalier de l'Université de Montréal (CHUM)

${ }^{3}$ Cardiology division, Département de Médecine du Centre Hospitalier de l'Université de Montréal (CHUM)

Corresponding author: François Tournoux

University of Montreal Hospital Research Centre (CRCHUM),

900 St Denis Street R11- 732, QC H2X 0A9, Montreal, Canada.

Email: francois.tournoux@umontreal.ca

Declaration of interest: none. 
medRxiv preprint doi: https://doi.org/10.1101/2021.04.14.21255509; this version posted April 20, 2021. The copyright holder for this preprint (which was not certified by peer review) is the author/funder, who has granted medRxiv a license to display the preprint in perpetuity. It is made available under a CC-BY-NC-ND 4.0 International license .

\section{ABSTRACT}

Background: Immunoglobulin light chain $(A L)$ amyloidosis is a complex disease marked by a poor clinical portrait and prognosis generally leading to organ dysfunction and shortened survival. We aimed to review the available evidence on whether $\mathrm{AL}$ amyloidosis can lead to malnutrition, thus having a negative impact on quality of life (QoL) and survival.

Materials: We searched Pubmed with no restrictions to the year of publication or language. Retrospective or prospective, observational, and interventional studies that reported data regarding $A L$ amyloidosis and nutritional status were included.

Results: From 62 articles retrieved, 23 were included. Malnutrition was prevalent in up to $65 \%$ of patients with AL Amyloidosis. Prevalence of weight loss of $10 \%$ or more ranged from 6 to $22 \%$ of patients, while a body mass index of $<22 \mathrm{~kg} / \mathrm{m} 2$ was found in 22 to $42 \%$. Weight loss, lower $\mathrm{BMI}$ and other indicators of poor nutritional status were negatively associated with quality of life and survival. Only one RCT focused on nutritional counseling was found and reported positive results on patients QoL and survival.

Conclusion: Despite inconsistencies across assessment criteria, the available data reveal that weight loss and malnutrition are common features in patients with $A L$ amyloidosis. This review reinforces the premise that an impaired nutritional status can be negatively associated with QoL and survival in patients with AL amyloidosis, and therefore should be further investigated. 
medRxiv preprint doi: https://doi.org/10.1101/2021.04.14.21255509; this version posted April 20, 2021. The copyright holder for this preprint (which was not certified by peer review) is the author/funder, who has granted medRxiv a license to display the preprint in perpetuity. It is made available under a CC-BY-NC-ND 4.0 International license .

\section{INTRODUCTION}

Amyloidosis is a disorder in which insoluble amyloid fibrils accumulate in the extracellular space of organs and tissues, causing irreversible organ dysfunction and death ${ }^{1,2}$. Amyloidosis can be localized or systemic. Organs commonly involved include the kidneys, heart, peripheral and autonomic nervous system, liver, and gastrointestinal tract ${ }^{3,4}$.

There are several types of amyloidosis, one of the most common types in developed countries being immunoglobulin light chain $(A L)$ amyloidosis ${ }^{3,5}$. The clinical portrait of $A L$ amyloidosis varies substantially and depends largely on the disease stage and involved organ(s). Clinical manifestations such as restrictive cardiomyopathy, nephrotic syndrome, hepatic failure, and peripheral/autonomic neuropathy can be linked to AL amyloidosis ${ }^{6}$. Frequent red flags that can be associated with $\mathrm{AL}$ amyloidosis onset or progression include gastrointestinal symptoms like nausea, vomiting, diarrhea, malabsorption, and weight loss (WL). As a result, the nutritional status of these patients can be compromised, and the cause is likely to be multifactorial ${ }^{7}$ (figure 1 ).

The nutritional status of patients is often neglected in the medical care pathway but may have considerable effects on physiological function ${ }^{8}$. Poor nutritional status in patients with $A L$ amyloidosis may be a consequence and/or be a factor that contributes to the progression of the disease. Malnutrition is known to have a negative impact on several outcomes that include reduced quality of life (QoL), increased morbidity and mortality, clinical complication rates, and length of hospital stay. All these elements contribute to the increasing burden of health costs ${ }^{9-}$ 11. In this way, assessing nutritional status is an essential part of caring for patients with $A L$ amyloidosis, to allow appropriate nutritional treatment and to prevent poor clinical outcomes. Several different criteria have been used to detect malnutrition in the general population. The most widely used are WL (with different cut points), anthropometry, body composition, reduced food intake, and subjective professional evaluation ${ }^{12-14}$.

Although WL has been a symptom commonly reported in patients with AL amyloidosis 6,15 , the nutritional status of these patients has not been deeply explored in the literature. A few studies have reported that malnutrition is highly prevalent and an independent predictor of survival among patients with $\mathrm{AL}$ amyloidosis ${ }^{16,17}$. To date, there is no gold standard tool to assess nutritional status, neither does there exist a clear description of the clinical nutritional condition of these patients.

Our study aimed to review the available evidence on the nutritional status of patients with $\mathrm{AL}$ amyloidosis and its association with QoL and survival. 
medRxiv preprint doi: https://doi.org/10.1101/2021.04.14.21255509; this version posted April 20, 2021. The copyright holder for this preprint (which was not certified by peer review) is the author/funder, who has granted medRxiv a license to display the preprint in perpetuity. It is made available under a CC-BY-NC-ND 4.0 International license .

\section{METHODS}

This rapid review was designed and conducted in accordance with the Preferred Reporting Items for Systematic Reviews and Meta-Analyses (PRISMA) guidelines ${ }^{18}$.

\section{Data Sources and Search Strategy}

The electronic search was conducted on PUBMED with a combination of MeSH terms and keywords searched for titles and abstracts. The following conjugated search terms were used: (immunoglobulin light chain amyloidosis OR immunoglobulin light-chain amyloidoses OR amyloidosis, primary $O R$ al amyloidosis $O R$ al amyloidoses OR primary systemic amyloidosis OR amyloidoses, primary systemic OR amyloidosis, primary systemic OR primary systemic amyloidoses OR systemic amyloidosis, primary) AND (nutrition OR undernutrition OR malnutrition $O R$ mal-nutrition OR malnourished OR underweight OR under-weight OR weight loss OR body mass index OR cachexia OR nutritional status).

The search was performed on August 12, 2020. There were no restrictions concerning the year of publication or language. Bibliographic references of the selected articles were manually screened for additional eligible studies by a single reviewer (SSG) and discussed with a second reviewer (PABR) as needed. We also contacted investigators by email to enquire about additional data when necessary. All retrieved data were screened using a bibliographic management program (EndNote®, version $\times 9$ ). The database was not blinded to the authors, institutions, or publication journals. All studies that provided enough information about the inclusion and exclusion criteria were selected for full-text assessment.

\section{Inclusion Criteria}

Original cross-sectional, observational studies, cohorts and clinical trials were included. Studies on experimental animal models, reviews, and case-reports were excluded. In addition, studies that did not clearly report the nutritional data or for which the authors did not respond to our inquiry were also excluded.

\section{Data Extraction}

Data extraction was performed by a single reviewer and revised by a second, using a pre-established data extraction form. Information extracted included author names, year of 
medRxiv preprint doi: https://doi.org/10.1101/2021.04.14.21255509; this version posted April 20, 2021. The copyright holder for this preprint (which was not certified by peer review) is the author/funder, who has granted medRxiv a license to display the preprint in perpetuity. It is made available under a CC-BY-NC-ND 4.0 International license .

publication, country, study design, number of study participants, the age range, type of population, organ involvement, stage of the disease, and data of nutritional status (BMI, WL, malnutrition), in addition to outcomes of QoL and survival according to nutritional parameters.

\section{Data interpretation}

Malnutrition was considered as defined by the authors. When lacking categorization of the outcomes of interest (i.e. BMI, WL and other nutritional parameters) they were extracted and presented according to the Global Leadership Initiative in Malnutrition (GLIM) ${ }^{19}$. To diagnose malnutrition, based on GLIM criteria, at least one phenotypic criterion and one etiologic criterion should be present. The phenotypic criteria include: 1) non-intentional WL ( $>5 \%$ within past 6 months or $>10 \%$ beyond past 6 months); 2) low BMI $\left(<20 \mathrm{~kg} / \mathrm{m}^{2}\right.$ for adults $<70$ years, or $<22$ $\mathrm{kg} / \mathrm{m}^{2}$ if 70 years and older); or 3 ) reduced muscle mass. The etiologic criteria include: 1) reduced food intake; 2) presence of gastrointestinal symptoms that cause malabsorption; and 3) disease-related inflammation.

\section{RESULTS}

Our search strategy retrieved 62 records, and we identified 23 studies that satisfied the inclusion criteria (Figure 2 - Study flowchart). Table 1 describes the studies;; characteristics and outcomes of interest. The nutritional status of patients, such as malnutrition parameters, were often not clearly reported. For 10 studies, we were able to identify and extract at least one parameter recommended by GLIM criteria, even if partially fulfilled (details in Table 2). The cut points differed among studies, and none of them evaluated all the parameters necessary to completely fulfill the GLIM diagnosis criteria $16,17,20,21,24,27,29,30,32,33$. Four studies presented a formal definition of malnutrition other than GLIM ${ }^{16,17,20,32}$.

\section{Characteristics of the studies}

Studies were published between 1993 and 2020. Most of the studies were conducted in

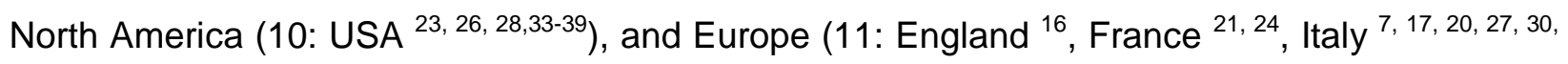
${ }^{32}$, Poland ${ }^{22}$, Denmark ${ }^{31}$ ). One was from Asia (Korea ${ }^{25}$ ), and one from Central America

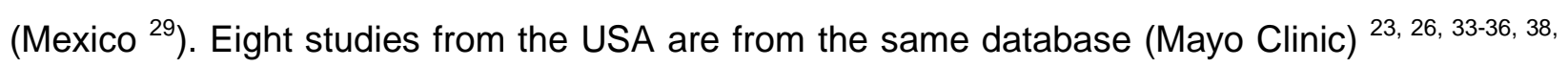
39, and the 6 Italian studies are from the same institution 7, 17, 20, 27, 30, 32 .

In these studies, sample sizes ranged from 8 to 474 patients, totaling 2562 patients, though there is likely overlap of patients across studies from the center $7,17,20,23,26,27,30,32,33-36,38$, 
medRxiv preprint doi: https://doi.org/10.1101/2021.04.14.21255509; this version posted April 20, 2021. The copyright holder for this preprint (which was not certified by peer review) is the author/funder, who has granted medRxiv a license to display the preprint in perpetuity. It is made available under a CC-BY-NC-ND 4.0 International license .

39. Overall, men accounted for $61.7 \%$ of the population, age ranged from 25 to 98 years. The studies included patients with various principal organ(s) involvement and different stages of the disease. Cohort studies were predominant, and only two studies presented data from interventional trials: one study had a randomized controlled clinical trial design ${ }^{20}$, and another was a phase 2 clinical trial ${ }^{33}$.

\section{Malnutrition}

Four studies 16, 17, 20, 32 presented a formal malnutrition diagnosis according to four different criteria, with a range of prevalence from $25 \%$ to $65 \%$. Caccialanza et al. ${ }^{20}$ reported that $52 \%$ of the $\mathrm{AL}$ amyloidosis patients had malnutrition according to the phase angle (PhA) derived from bioelectrical impedance. The authors used the median value of the sample as the cut point to detect malnutrition (PhA $\leq 4.30 \square$ ). One study ${ }^{16}$ assessed malnutrition using the PatientGenerated Subjective Global Assessment (PG-SGA) score. This study showed that $65 \%$ of the patients had a PG-SGA score equal to or greater than 4 (defined as malnutrition by the authors). No correlation between BMI and nutritional status by PG-SGA was found ( $r=-0.14)$. Cacciallanza et al. ${ }^{17}$, assessed malnutrition according to $\mathrm{BMI}<22 \mathrm{~kg} / \mathrm{m}^{2}$ and unintentional WL in the previous 6 months (WL when $\geq 10 \%$ ). The results showed a prevalence of moderate (presence of one parameter) and severe malnutrition (both parameters combined) of $21.9 \%$ and $7.8 \%$, respectively. Cacciallanza et al. ${ }^{30}$ considered a cut point of $\mathrm{BMI}<22 \mathrm{~kg} / \mathrm{m}^{2}$ as a criterion for malnutrition and classified nearly $25 \%$ of the patients as malnourished. They also reported $\mathrm{BMI}<18.5 \mathrm{~kg} / \mathrm{m}^{2}$, a classification of underweight according to the $\mathrm{WHO}$, in $2.8 \%$ of patients ${ }^{40}$.

\section{Weight Loss}

Detailed data of WL is presented in Table 1. Of the 23 selected studies, only one ${ }^{24}$ did not provide any data on WL. Twelve 7, 17, 20, 21, 27, 30-32, 34, 35, 38, 39 studies presented WL as descriptive data (mean, median or range) ranging from 0 to $30 \mathrm{~kg}$ or from 2 to 200lb. Fourteen studies highlighted the prevalence of any amount of WL, and it ranged from $28.3 \%$ to $100 \%^{16,21,22,25,26,28,30-35,38,39}$. Considering a percentage of WL greater than $10 \%$, six studies reported a prevalence ranging from $6 \%$ to $31.5 \%$ of the patients $17,20,27,29,30,33$. The results from the RCT demonstrated that an intervention with nutritional counseling during 12 months allowed 
medRxiv preprint doi: https://doi.org/10.1101/2021.04.14.21255509; this version posted April 20, 2021. The copyright holder for this preprint (which was not certified by peer review) is the author/funder, who has granted medRxiv a license to display the preprint in perpetuity. It is made available under a CC-BY-NC-ND 4.0 International license .

patients with systemic $A L$ amyloidosis to maintain their weight $(\mathrm{WL}=0.6 \mathrm{~kg} ; p=0.214)$, while patients in the usual care group had a significant decrease $(\mathrm{WL}=2.1 \mathrm{~kg} ; p=0.003)^{20}$.

\section{Body Mass Index}

Table 1 presents the studies that described data of BMI in patients with $\mathrm{AL}$ amyloidosis $(k=10)$. All of them reported mean $( \pm S D)$ or median (range/lQR) BMI. The mean ranged from 19.3 to $29.2 \mathrm{~kg} / \mathrm{m}^{2}$, and the median ranged from 17.5 to $33.7 \mathrm{~kg} / \mathrm{m}^{2} 7,16,17,20-22,24,27,30,32$. Seven studies presented BMI with different cut points. The percentage of patients with a BMI < $22 \mathrm{~kg} / \mathrm{m}^{217,20,21,30,32}$ ranged from $21.9 \%$ to $41.7 \%$ and from $3.63 \%-14 \%$ for $\mathrm{BMI}<20 \mathrm{~kg} / \mathrm{m}^{2} 16,24$.

\section{Association between self-reported quality of life and nutritional status}

Four studies ${ }^{7,16,20,30}$ investigated the association between nutritional status and QoL, using the Medical Outcomes Study 36-item Short-Form General Health Survey (SF-36), 7, 20, 30 or the European Organization for Research and Treatment of Cancer (EORTC) QLQ-C30 ${ }^{16}$. Sattianayagam et al. ${ }^{16}$, demonstrated that more severe malnutrition evaluated by the PG-SGA score correlated with lower QoL scores $(p<0.001)$, including lower functional and higher symptom scores. Calccialanza et al. ${ }^{30}$, demonstrated that the mental component summary was decreased by $0.47(95 \% \mathrm{Cl} 0.18-0.75, p=0.002)$ for each kilogram of $\mathrm{WL}$ in the previous 6 months. In addition, one study observed that patients with a lower value of the PhA had lower Physical Health Composite Scale (PCS) scores $(p=0.015)^{20}$. Finally, the randomized clinical trial showed a significant increase in the mental component summary after receiving nutritional counselling, and patients were able to achieve a mean score of 53 (95\% Cl, 50-53), which is above the healthy population norms ${ }^{7}$.

\section{Association between survival and nutritional parameters}

Overall, 7 studies reported survival rates according to nutritional parameters (details in Table 1) ${ }^{16,17,20,24,32,35,36}$. The results were presented as hazard ratios or relative risk, with a range from 0.75 to 6.4 , depending on the parameter and cut point analyzed. A score higher than 9 on PG-SGA was associated with higher mortality $(\mathrm{HR}=6.4 ; 95 \% \mathrm{IC} 1.4-30.2)^{16}$. Weight loss, $\mathrm{BMI}<$ $22 \mathrm{~kg} / \mathrm{m} 2$ and low PhA $(\leq 4.30 \square)$ were also independently associated with mortality ${ }^{17,20,32,36}$. 
medRxiv preprint doi: https://doi.org/10.1101/2021.04.14.21255509; this version posted April 20, 2021. The copyright holder for this preprint (which was not certified by peer review) is the author/funder, who has granted medRxiv a license to display the preprint in perpetuity. It is made available under a CC-BY-NC-ND 4.0 International license .

Furthermore, patients who received nutritional counseling had a lower mortality risk than those who did not (HR 0.57; 95\%IC 0.35-0.94) ${ }^{7}$.

\section{DISCUSSION}

Our results suggest that $A L$ Amyloidosis has a negative impact on the nutritional status of patients. Most of the evidence on nutritional status is derived from retrospective data. The included studies provided nutritional status prevalence that varied markedly depending on the assessment tool, criteria used, organs involved, and disease stage. The prevalence of malnutrition in $\mathrm{AL}$ amyloidosis patients ranged from $25 \%$ to $65 \%$. This wide range is likely a consequence of inconsistent diagnostic criteria across studies and the disease's heterogeneity, but nevertheless the results indicate that malnutrition is consistently highly prevalent.

Caccialanza et al. ${ }^{20}$, using BIA technology, found that $52 \%$ of patients had malnutrition. While this measurement technique is objective, easy to perform, non-invasive and inexpensive ${ }^{53}$, the cut point to detect malnutrition is unclear. The authors used the median of the $\mathrm{PhA}$ as a diagnostic measure and as a prognostic threshold value. Low values of PhA have been previously associated with malnutrition according to different cut-off points varying from $4.0^{\circ}$ to $6.0^{\circ 54}$. One study assessed malnutrition with $\mathrm{PG}-\mathrm{SGA}^{16}$ and showed the highest prevalence of malnutrition (65\% of the patients), probably because this tool uses a combination of parameters (i.e., WL, dietary intake, gastrointestinal symptoms, functional capacity, nutritional requirements according to the disease and physical evaluation). In the absence of a gold standard method to detect malnutrition, the SGA is considered one of the best assessment tools since it has been validated and is predictive of outcomes in many clinical conditions, including cancer $^{41-43}$. In the studies of Caccialanza et al. ${ }^{7,27,30,32}$, mid-arm muscle circumference, caloric and protein intake were assessed in combination with BMI and WL to better evaluate the nutritional status.

These findings are consistent with those that showed malnutrition in patients with similar characteristics of our studied population. Despite also having a large variance in diagnosis and reporting, malnutrition has a prevalence ranging from $16 \%$ to $62.4 \%$ in stable heart failure ${ }^{44}$, and it is as high as $80 \%$ in patients with advanced heart failure ${ }^{45}$. Among older cancer patients under chemotherapy, malnutrition studies showed prevalence from 3 to $83 \%{ }^{46}$. Also, aging itself 
medRxiv preprint doi: https://doi.org/10.1101/2021.04.14.21255509; this version posted April 20, 2021. The copyright holder for this preprint (which was not certified by peer review) is the author/funder, who has granted medRxiv a license to display the preprint in perpetuity. It is made available under a CC-BY-NC-ND 4.0 International license .

may also induce deterioration in nutritional status due to multiple factors ${ }^{47}$, which could partially explain the high prevalence we observed.

The highest inconsistency was found in reporting the prevalence of WL, that ranged from $6 \%$ to $100 \%$ due multiple cut-off points (e.g. WL> $10 \mathrm{~kg}^{22,31}, \mathrm{WL} \geq 10 \mathrm{lb}^{36,37}, \mathrm{WL}>20 \mathrm{lb}^{35,37}$, $\mathrm{WL}>100 \mathrm{lb}^{38}, \mathrm{WL} \geq 5 \%$ and $\mathrm{WL} \geq 10 \%$ of the usual body weight ${ }^{17,20,27,29,30,33}$ ). Interestingly, most studies did not even use a cut point and presented the prevalence based on any amount of WL 16,21,23,25,26,28,30-35,38,39. Moreover, most studies have not indicated the timeframe for WL, which is critically relevant. These inconsistencies render it difficult to interpret and compare the data across studies. Furthermore, many patients with systemic AL amyloidosis experience fluid retention, usually due to cardiac and renal involvement. This can impair accurate assessment of nutritional status by WL and $\mathrm{BMI}^{48}$ and also interfere with the interpretation of the results.

According to $\mathrm{BMI}$, the prevalence of malnutrition in this population ranged from $2.8 \%$ to $41.7 \% 16,17,21,24,30,32$. Although low BMI is commonly accepted in the medical community, used alone it is a poor indicator of malnutrition, and can misclassify malnourished patients within the normal range ${ }^{49}$. Perhaps, for this reason, the study that assessed malnutrition using this criterion alone had the lowest prevalence. Also, BMI may not be reliable in the presence of confounding factors, such as edema or ascites, and may not identify significant unintended WL when used as a single assessment ${ }^{49}$. Therefore, we believe BMI should be used in combination to $\mathrm{WL}$ and/or other parameters to better evaluate malnutrition.

Quality of life among patients with AL Amyloidosis has not been extensively studied ${ }^{16,30,}$ 50-52. However, some studies have already shown that the impact of the disease results in broad health-related QoL deficits across physical and mental domains when compared to the general population $^{30,50-52}$. Overall, QoL seems to be associated with nutritional status 16, 20, 30 independently of other relevant clinical variables, including disease stage, organ involvement and age $^{30}$. Interestingly, the only randomized clinical trial with nutritional counseling intervention showed an improvement in the mental component of QoL, but no effect on physical component $^{7}$. There was also a trend toward maintaining body weight, improve calorie intake, and survival ${ }^{7}$.

Survival in AL amyloidosis depends greatly on the stage of the disease and the organs in which light chain fibrils are deposited. Poor nutritional status, however, despite being a prevalent condition among these patients, has thus far garnered little attention in survival analyses. Furthermore, although malnutrition is a public health issue already proven to be 
medRxiv preprint doi: https://doi.org/10.1101/2021.04.14.21255509; this version posted April 20, 2021. The copyright holder for this preprint (which was not certified by peer review) is the author/funder, who has granted medRxiv a license to display the preprint in perpetuity. It is made available under a CC-BY-NC-ND 4.0 International license .

associated with incremental morbidity, mortality, and health costs, there has been a lack of evidence in particular settings ${ }^{19}$, including amyloidosis patients. In our review, 7 studies tested the association between nutritional status and survival ${ }^{16}, 17,20,24,32,35,36$ all using different nutritional parameters, making it difficult to determine which assessment tool should be used and the real impact on survival.

Finally, assuming that nutritional status is a modifiable risk factor, the evidence from our review reinforces the importance of a standardized nutritional status assessment, enabling tailored nutritional intervention as soon as possible. Patients with $\mathrm{AL}$ amyloidosis have a broad spectrum of symptoms, and for that reason we believe that diagnostic criteria covering different domains, instead of using single parameters, would be more appropriate. In this context, the GLIM consensus is an initiative led by the American Society for Parenteral and Enteral Nutrition (ASPEN) proposing criteria that consider a combination of phenotypic and etiologic parameters. In light of the complexity of the clinical manifestations, we strongly believe that a more holistic approach such GLIM could successfully be used in clinical practice and optimize patients' management.

Some limitations require acknowledgment in this review. First, we considered only PubMed retrievals; using the identical search strategy on EMBASE yielded zero retrievals. Second, most of the studies mentioned did not report nutritional status as a primary outcome, which underscores the need for more data. Finally, due to the different criteria and cut points used to assess malnutrition and WL, quantitative summarization of the results was not possible (i.e., meta-analysis).

\section{CONCLUSION}

In conclusion, our review shows a high prevalence of $\mathrm{WL}$ and malnutrition in $\mathrm{AL}$ amyloidosis patients. Our study also has many strengths, such as methodological rigor and being the first to analyze the evidence and highlight the importance of properly assess nutritional status and its potential impact on patients' QoL and survival. As most of the evidence comes from retrospective studies, it is difficult to evaluate the disease's true impact on nutritional status and its association with QoL and survival. We believe that criteria standardization and proper assessment tools will promote better understanding. It is clear that some effort should be invested in testing and validating accurate tools in this population, such 
medRxiv preprint doi: https://doi.org/10.1101/2021.04.14.21255509; this version posted April 20, 2021. The copyright holder for this preprint (which was not certified by peer review) is the author/funder, who has granted medRxiv a license to display the preprint in perpetuity. It is made available under a CC-BY-NC-ND 4.0 International license.

as the GLIM criteria. Overall, the available data suggest that we need to improve assessment to be able to offer treatment to optimize health care in this population.

\section{Acknowledgments}

We thank Dr. Annabel Chen-Tournoux for the critical review of this manuscript.

\section{Authors' contributions}

Conception and design of the research: SSG, PZ, PABR, FT; Analysis and interpretation of the data: SSG, PZ, PABR, FT; Writing of the manuscript: SSG, PZ, PABR, FT; Critical revision of the manuscript for intellectual content: PABR, FT; Final review: SSG, SB, PABR, ELB, BL, FT.

Funding support: Scholarship from Fonds de recherche du Quebec - Nature et Technologies (FRQNT) for SSG. FT is supported by a grant from Fonds de recherche du Québec - Santé. This research did not receive any other specific grant from funding agencies in the public, commercial, or not-for-profit sectors.

Conflict of interest: None of the authors have any financial or personal relationships with other people or organizations that could inappropriately influence this work. 
medRxiv preprint doi: https://doi.org/10.1101/2021.04.14.21255509; this version posted April 20, 2021. The copyright holder for this preprint (which was not certified by peer review) is the author/funder, who has granted medRxiv a license to display the preprint in perpetuity. It is made available under a CC-BY-NC-ND 4.0 International license .

\section{REFERENCES}

1. Wechalekar AD, Gillmore JD, Hawkins PN. Systemic amyloidosis. Lancet 2016; 387(10038): pp. 2641-2654.

2. Gertz M.A.: Immunoglobulin light chain amyloidosis: 2016 update on diagnosis, prognosis, and treatment. Am J Hematol 2016; 91: pp. 947-956

3. Kyle RA, Linos A, Beard CM, et al. Incidence and natural history of primary systemic amyloidosis in Olmsted County, Minnesota, 1950 through 1989. Blood 1992; 79: 1817-22.

4. Merlini G, Seldin DC, Gertz MA. Amyloidosis: pathogenesis and new therapeutic options. J Clin Oncol 2011; 29:1924-33.

5. Palladini G, Merlini G. What is new in diagnosis and management of light chain amyloidosis? Blood. 2016; 128(2):159-168.

6. Gertz M.A.: Immunoglobulin light chain amyloidosis: 2018 update on diagnosis, prognosis, and treatment. Am J Hematol 2018; 93: pp. 1169-80

7. Caccialanza R, Palladini G, Cereda E, et al. Nutritional counseling improves quality of live and preserves body weight in systemic immunoglobulin light-chain (AL) amyloidosis. Nutrition. 2015;31: pp1228-34.

8. Saunders J, Smith T. Malnutrition: causes and consequences. Clin Med (Lond). 2010;10(6):624-627. doi:10.7861/clinmedicine.10-6-624

9. Ryan AM, Prado CM, Sullivan ES, et al. Effects of weight loss and sarcopenia on response to chemotherapy, quality of life, and survival. Nutrition 2019; 67: 110539.

10. Correia MI, Waitzberg DL. The impact of malnutrition on morbidity, mortality, length of hospital stay and costs evaluated through a multivariate model analysis. Clin Nutr 2003; 22(3):235e9.

11. Rasheed S., and Woods R.T.: Malnutrition and quality of life in older people: a systematic review and meta-analysis. Ageing Res Rev 2013; 12: pp. 561-566 
medRxiv preprint doi: https://doi.org/10.1101/2021.04.14.21255509; this version posted April 20, 2021. The copyright holder for this preprint (which was not certified by peer review) is the author/funder, who has granted medRxiv a license to display the preprint in perpetuity. It is made available under a CC-BY-NC-ND 4.0 International license .

12. Cederholm TA, Bosaeus IB, Barazzoni RC, et al. Diagnostic criteria for malnutrition e an ESPEN Consensus Statement.

13. Reber E, Gomes F, Vasiloglou MF, et al. Nutritional Risk Screening and Assessment. J Clin Med 2019; 8(7): pp: 1065.

14. Fink JS, Mello PD, Mello ED. Subjective global assessment of nutritional status e A systematic review of the literature. Clinical Nutrition 2015; 34: pp. 785-792.

15. Gertz MA, Dispenzieri A. Systemic Amyloidosis Recognition, Prognosis, and Therapy: A Systematic Review. JAMA. 2020;324(1):79-89. doi:10.1001/jama.2020.5493

16. Sattianayagam PT, Lane T, Fox Z, et al. A prospective study of nutritional status in immunoglobulin light chain amyloidosis. Haematologica 2013; 98 (1): pp 136-140.

17. Caccialanza R, Palladini G, Klersy C, et al. Malnutrition at diagnosis predicts mortality in patients with systemic immunoglobulin light-chain amyloidosis independently of cardiac stage and response to treatment. JPEN J Parenter Eternal Nutr 2014; 38: pp. 891-894.

18. Moher D, Liberati A, Tetzlaff J, Altman DG, PRISMA Group . Preferred reporting items for systematic reviews and meta $\square$ analyses: the PRISMA statement. PLoS 2009; 6:e1000097

19. Cederholm T., Jensen G.L., Correia M.I.T., Gonzalez M.C., Fukushima R., Higashiguchi T., Baptista G., Barazzoni R., Blaauw R., Coats A.J., et al. ESPEN Endorsed Recommendation GLIM criteria for the diagnosis of malnutrition e A consensus report from the global clinical nutrition community. Clin. Nutr. 2019;38:1-9. doi: 10.1016/j.clnu.2018.08.002.

20.Caccialanza R, Cereda E, Klersy C, et al. Bioelectrical impedance vector analysis-derived phase angle predicts survival in patients with systemic immunoglobulin light-chain amyloidosis. Amyloid. 2020 Sep;27(3):168-173. doi: 10.1080/13506129.2020.1737004. Epub 2020 Mar 26. PMID: 32212933.

21. Bartier S, Bodez D, Kharoubi M, et al. Pharyngo-laryngeal involvement in systemic amyloidosis with cardiac involvement: a prospective observational study, Amyloid 2019; 26 (4): 216-24. 
medRxiv preprint doi: https://doi.org/10.1101/2021.04.14.21255509; this version posted April 20, 2021. The copyright holder for this preprint (which was not certified by peer review) is the author/funder, who has granted medRxiv a license to display the preprint in perpetuity. It is made available under a CC-BY-NC-ND 4.0 International license .

22. Szczygiel JA, Wieczorek PZ, Drozd-Skolowska J, et al. Impaired right ventricular function as a predictor of early mortality in patients with light-chain cardiac amyloidosis assessed in a cardiology department. Pol Arch Intern Med. 2017; 127(12):854-864.

23. Liewluck T, Milone M. Characterization of isolated amyloid myopathy. Eur J Neurol. 2017; 24(12):1437-1445.

24. Decourt A, Gondouin B, Delaroziere JC, et al. Trends in Survival and Renal Recovery in Patients with Multiple Myeloma or Light-Chain Amyloidosis on Chronic Dialysis. Clin J Am Soc Nephrol. 2016; 11(3):431-41.

25. Lim AY, Lee JH, Jung KS, et al.Clinical features and outcomes of systemic amyloidosis with gastrointestinal involvement: a single-center experience. Korean J Intern Med. 2015; 30(4):496505.

26. Said SM, Grogg KL, Smyrk TC. Gastric amyloidosis: clinicopathological correlations in 79 cases from a single institution. Hum Pathol. 2015; 46(4):491-8.

27. Caccialanza R, Palladini G, Klersy C, et al. Serum prealbumin: An independent marker of short-term energy intake in the presence of multiple-organ disease involvement. Nutrition. 2013 Mar; 29(3):580-2.

28. Cowan Aj, Skinner M, Seldin DC, et al. Amyloidosis of the gastrointestinal tract: a 13-year, single-center, referral experience. Haematologica. 2013 Jan; 98(1):141-6.

29. Hermandez-Reyes J, Galo-Hooker E, Ruiz-Delgado GJ, et al. Systemic immunoglobulin light-chain amyloidosis (AL) in Mexico: a single institution, 30-year experience. Rev Invest Clin. 2012; 64(6 Pt 2):604-8.

30. Caccialanza R, Palladini G, Klersy C, et al. Nutritional status independently affects quality of life of patients with systemic immunoglobulin light-chain (AL) amyloidosis. Annals of Hematology 2012; 91: 399-406.

31. Madsen LG, Gimsing P, Schiodt FV. Primary (AL) amyloidosis with gastrointestinal involvement. Scand J Gastroenterol. 2009; 44(6):708-11. 
medRxiv preprint doi: https://doi.org/10.1101/2021.04.14.21255509; this version posted April 20, 2021. The copyright holder for this preprint (which was not certified by peer review) is the author/funder, who has granted medRxiv a license to display the preprint in perpetuity. It is made available under a CC-BY-NC-ND 4.0 International license .

32. Caccialanza R, Palladini G, Klersy C, et al. Nutritional status of outpatients with systemic immunoglobulin light-chain amyloidosis. Am J Clin Nutr. 2006;83(2):350-4.

33. Gertz MA, Blood E, Vesole DH, et al. A multicenter phase 2 trial of stem cell transplantation for immunoglobulin light-chain amyloidosis (E4A97): an Eastern Cooperative Oncology Group Study. Bone Marrow Transplant. 2004 Jul;34(2):149-54. doi: 10.1038/sj.bmt.1704539. PMID: 15156165 .

34. Park, MA, Mueller PS, Kyle RA, et al. Primary (AL) Hepatic Amyloidosis Clinical Features and Natural History in 98 Patients. Medicine (Baltimore). 2003; 82(5):291-8.

35. Hayman SR, Lacy MQ, Kyle RA, et al. Primary Systemic Amyloidosis: A Cause of Malabsorption Syndrome. Am J Med. 2001; 111(7):535-40.

36. Dispenzieri A, Lacy MQ, Kyle RA, Eligibility for Hematopoietic Stem-Cell Transplantation for Primary Systemic Amyloidosis Is a Favorable Prognostic Factor for Survival. J Clin Oncol. 2001 Jul 15; 19(14):3350-6.

37. Dubrey SW, Cha K, Anderson J, et al. The clinical features of immunoglobulin light-chain (AL) amyloidosis with heart involvement. QJM. 1998 Feb; 91(2):141-57.

38. Kyle RA, Gertz MA. Primary Systemic Amyloidosis: Clinical and Laboratory Features in 474 cases. Semin Hematol. 1995 Jan; 32(1):45-59.

39. Menke DM, Kyle RA, Fleming R, et al. Symptomatic Gastric Amyloidosis in Patients with Primary Systemic Amyloidosis. Mayo Clin Proc. 1993 Aug; 68(8):763-7.

40. OrganizationWH: WHO/Europe Nutrition - Body Mass Index - BMI41. Li R., Wu J., Ma M., Pei J., Song Y., Zhang X., Han B. Comparison of PG-SGA, SGA and body-composition measurement in detecting malnutrition among newly diagnosed lung cancer patients in stage IIIB/IV and benign conditions. Med. Oncol. 2011; 28:689-696.

42. Jeejeebhoy KN, Keller H, Gramlich L, Allard JP, Laporte M, Duerksen DR, et al. Nutritional assessment: comparison of clinical assessment and objective variables for the prediction of length of hospital stay and readmission. Am J Clin Nutr 2015; 101(5):956e65. 
medRxiv preprint doi: https://doi.org/10.1101/2021.04.14.21255509; this version posted April 20, 2021. The copyright holder for this preprint (which was not certified by peer review) is the author/funder, who has granted medRxiv a license to display the preprint in perpetuity. It is made available under a CC-BY-NC-ND 4.0 International license .

43. Silva Fink J, Daniel de Mello P, Daniel de Mello E. Subjective global assessment of nutritional status - a systemic review of the literature. Clin Nutr 2015: 34(5:785-92.

44. Lin H, Zhang H, Lin Z, Li X, Kong X, and Sun G: Review of nutritional screening and assessment tools and clinical outcomes in heart failure. Heart Fail Rev 2016; 21: pp. 549-565

45. Yost G, Gregory M, and Bhat G. Short-form nutrition assessment in patients with advanced heart failure evaluated for ventricular assist device placement or cardiac transplantation. Nutr Clin Pract 2014; 29: pp. 686-691

46. Philippe Caillet, Evelyne Liuu, Agathe Raynaud Simon et al. Association between cachexia, chemotherapy and outcomes in older cancer patients: A systematic review. Clinical Nutrition 2017; 36: 1473e1482

47. Hickson M. Malnutrition and ageing. Postgrad Med J 2006; 82:2-8.

48. Rezk T, Davenport A, Gan JJ, Lachmann HJ, Fontana M, Martinez-Naharro A, Sachchithanantham S, Guillotte C, Mahmood S, Petrie A, Whelan CJ, Pinney JH, Foard D, Lane T, Youngstein T, Wechalekar AD, Hawkins PN, Gillmore JD. Bioimpedance vector analysis for the detection of extracellular volume overload and sarcopenia in systemic AL amyloidosis. Br $\mathbf{J}$ Haematol. 2019 Jun;185(5):977-980. doi: 10.1111/bjh.15675. Epub 2018 Nov 18. PMID: 30450572.

49. Cook, Z., Kirk, S., Lawrenson, S., \& Sandford, S. Use of BMI in the assessment of undernutrition in older subjects: Reflecting on practice. Proceedings of the Nutrition Society 2005, 64(3), 313-317.

50. Sanchorawala V, McCausland KL, White MK, et al. A longitudinal evaluation of healthrelated quality of life in patients with AL amyloidosis: associations with health outcomes over time. Br J Haematol. 2017 Nov; 179(3):461-470.

51. Bayliss, M., McCausland, K.L., Guthrie, S. \& White, M.K. The burden of amyloid light chain amyloidosis on health-related quality of life. Orphanet Journal of Rare Diseases 2017; 12, 15. 
medRxiv preprint doi: https://doi.org/10.1101/2021.04.14.21255509; this version posted April 20, 2021. The copyright holder for this preprint (which was not certified by peer review) is the author/funder, who has granted medRxiv a license to display the preprint in perpetuity. It is made available under a CC-BY-NC-ND 4.0 International license.

52. Seldin, D.C., Anderson, J.J., Sanchorawala, V., Malek, K., Wright, D.G., Quillen, K., Finn, K.T., Berk, J.L., Dember, L.M., Falk, R.H. \& Skinner, M. Improvement in quality of life of patients with AL amyloidosis treated with highdose melphalan and autologous stem cell transplantation. Blood 2004; 104: 1888-1893.

53. Cotogni P, Monge T, Fadda M, et al. Bioelectrical impedance analysis for monitoring cancer patients receiving chemotherapy and home parenteral nutrition. BMC Cancer 2018;18(1):990.

54. Pereira MME, Queiroz M, de Albuquerque NMC, et al. The prognostic role of phase angle in advanced cancer patients: a systematic review. Nutr Clin Pract. 2018;33(6):813-824. 
Table 1. Studies' characteristics and summary of outcomes of interest according to nutritional status criteria

\begin{tabular}{|c|c|c|c|c|c|c|c|c|c|}
\hline $\begin{array}{l}\text { Author, } \\
\text { Year; } \\
\text { Country }\end{array}$ & $\begin{array}{c}\text { Study } \\
\text { population }\end{array}$ & Study design & $\begin{array}{c}\text { Sample } \\
\text { size; } \\
\text { Age (years) } \\
\text { mean } \pm \text { SD; } \\
\text { Sex } \\
\text { proportions }\end{array}$ & $\begin{array}{c}\text { Stage of } \\
\text { disease; } \\
\text { Organ/system } \\
\text { involvement } \\
\text { (\%) }\end{array}$ & $\begin{array}{c}\text { BMI } \\
\left(\mathrm{kg} / \mathrm{m}^{2}\right) \\
\text { mean } \pm \text { SD }\end{array}$ & $\begin{array}{l}\text { Weight loss } \\
(\mathrm{Kg}) \\
\text { mean } \pm \text { SD }\end{array}$ & $\begin{array}{c}\text { Symptoms GI } \\
(\%)\end{array}$ & QoL & Survival \\
\hline $\begin{array}{l}\text { Caccialanza R, } \\
2020^{20} \\
\text { Italy }\end{array}$ & $\begin{array}{l}\text { Systemic AL } \\
\text { Amyloidosis, } \\
\text { Newly } \\
\text { diagnosed and } \\
\text { treatment- } \\
\text { naïve }\end{array}$ & $\begin{array}{l}\text { Prospective } \\
\text { cohort }\end{array}$ & $\begin{array}{l}n=127 \\
\text { Age } 64.1 \pm \\
9.9 \\
\text { Male } 54.3 \%\end{array}$ & $\begin{array}{l}\text { Mayo disease } \\
\text { stage } \\
\text { I- } 16.5 \\
\text { II - } 33.1 \\
\text { IIla - } 23.6 \\
\text { IIIb - } 26.8 \\
\text { Heart - } 83.5 \\
\text { Kidney - } 59.1 \\
\text { PNS - } 8.7 \\
\text { Liver - } 7.1\end{array}$ & $\begin{array}{l}23.8 \pm 3.7 \\
C:<22 \\
P: 32.3 \%\end{array}$ & $\begin{array}{l}8 \pm 7.4 \\
C: \geq 10 \% \\
P: 31.5 \%\end{array}$ & NR & $\begin{array}{l}\text { PhA } \leq 4.3: \\
\downarrow P C S \\
\text { score } \\
(p=0.015) \\
\text { MCS } \\
(p=0.16)\end{array}$ & $\begin{array}{l}\mathrm{PhA} \leq 4.3: \\
\mathrm{HR} 2.26 \\
95 \% \mathrm{Cl} \\
1.04-4.89\end{array}$ \\
\hline $\begin{array}{l}\text { Bartier S, } \\
2019^{21} \\
\text { France }\end{array}$ & $\begin{array}{l}\text { Cardiac } \\
\text { amyloidosis } \\
\text { (AL, ATTRwt, } \\
\text { ATTRv), }\end{array}$ & $\begin{array}{l}\text { Prospective } \\
\text { cohort }\end{array}$ & $\begin{array}{l}\text { AL } n=36 \\
\text { Age } 67.66 \\
\pm 1.4 \\
\text { Male } 66.7 \%\end{array}$ & $\begin{array}{l}\text { Prognostic } \\
\text { stage } \\
1-41.7 \\
2-41.7 \\
3-16.7 \\
\text { NR }\end{array}$ & $\begin{array}{l}\text { median } \\
22.9 * * \\
(\text { IQR } 19.8- \\
26.8) \\
\text { C: }<22 \\
P: 41.7 \%\end{array}$ & $\begin{array}{l}6 \pm 1.41 * * \\
P: 66.67 \% * *\end{array}$ & Dysphagia 25\% & NR & NR \\
\hline $\begin{array}{l}\text { Szczygiel, JA, } \\
2017^{22} \\
\text { Poland }\end{array}$ & $\begin{array}{l}\text { AL Cardiac } \\
\text { amyloidosis } \\
\text { Newly } \\
\text { diagnosed }\end{array}$ & $\begin{array}{l}\text { Prospective } \\
\text { cohort }\end{array}$ & $\begin{array}{l}\mathrm{n}=30 \\
\text { Age median } \\
61.5 \text { (IQR } \\
39-75) \\
\text { Male } 53.3 \%\end{array}$ & $\begin{array}{l}\text { ECOG PS } \\
1-23.3 \\
2-43.3 \\
3-10 \\
4-23.3 \\
\text { NR }\end{array}$ & $\begin{array}{l}\text { median } \\
25.23 \\
(\text { IQR 23.5- } \\
27.9)\end{array}$ & $\begin{array}{l}\text { NR } \\
C:>10 \mathrm{~kg} \\
P: 70 \%\end{array}$ & NR & NR & NR \\
\hline $\begin{array}{l}\text { Liewluck T, } \\
2017^{23} \\
\text { USA }\end{array}$ & $\begin{array}{l}\text { Amyloid } \\
\text { myopathy } \\
\text { (isolated } \\
\text { amyloid }\end{array}$ & $\begin{array}{l}\text { Cross- } \\
\text { sectional }\end{array}$ & $\begin{array}{l}\text { AL } n=32 \\
\text { Age median } \\
65.5\end{array}$ & $\begin{array}{l}\text { NR } \\
\text { Heart - } 59.4 \\
\text { Kidney }-15.6\end{array}$ & NR & $\begin{array}{l}\text { NR } \\
\text { C: any WL } \\
P: 28.13 \%\end{array}$ & $\begin{array}{l}\text { Dysphagia } \\
33.25 \%\end{array}$ & NR & NR \\
\hline
\end{tabular}




\begin{tabular}{|c|c|c|c|c|c|c|c|c|c|}
\hline Mayo Clinic & $\begin{array}{l}\text { myopathy and } \\
\text { systemic) }\end{array}$ & & $\begin{array}{l}\text { (range 50- } \\
78.5) \\
\text { Male } 62.5 \% \\
\end{array}$ & $\begin{array}{l}\text { GI - } 12.5 \\
\text { Lung }-6.3 \\
\text { Liver }-3.1\end{array}$ & & & & & \\
\hline $\begin{array}{l}\text { Decourt A, } \\
2016^{24}, \\
\text { France }\end{array}$ & $\begin{array}{l}\text { End-stage renal } \\
\text { disease } A L \\
\text { LCDD, or } M C N\end{array}$ & $\begin{array}{l}\text { Retrospective } \\
\text { cohort }\end{array}$ & $\begin{array}{l}\text { AL } n=267 \\
\text { Age } 70.6 \pm \\
14.6 \\
\text { Male } 64.4 \%\end{array}$ & $\begin{array}{l}\text { NR } \\
\text { NR }\end{array}$ & $\begin{array}{l}23.2 \pm 3.9 \\
C:<20 \\
P: 14 \%\end{array}$ & NR & NR & NR & $\begin{array}{l}\text { BMI <20: } \\
\text { HR 16.62 } \\
95 \% \mathrm{Cl} \\
11.21-23.61\end{array}$ \\
\hline $\begin{array}{l}\text { Caccialanza R, } \\
2015^{7} \\
\text { Italy }\end{array}$ & $\begin{array}{l}\text { AL Amyloidosis } \\
\text { outpatients, } \\
\text { treatment- } \\
\text { naïve }\end{array}$ & $\mathrm{RCT}$ & $\begin{array}{l}\mathrm{n}=144 \\
\text { Age } \\
\text { NC: } 65.4 \\
\pm 10.5 \\
\text { UC: } 64.8 \pm \\
9.7 \\
\text { Male } 61.1 \%\end{array}$ & $\begin{array}{l}\text { ECOG PS } \geq 2- \\
55.6 \\
\text { Heat - } 78.5 \\
\text { Kidney - } 62.5 \\
\text { Liver - } 13.2 \\
\text { Gl - } 4.9\end{array}$ & $\begin{array}{l}\text { NC: } 24.6 \pm \\
3.3 \\
\text { UC: } 25.4 \pm \\
4.1\end{array}$ & $\begin{array}{l}\text { NC: median } \\
3.0 \text { (IQR } \\
0.0-6.0) \\
\text { UC: median } \\
4.0 \text { (IQR } \\
0.3-7.0)\end{array}$ & $\begin{array}{l}\text { Anorexia } 45.9 \% \\
\text { Dysgeusia } 45.1 \% \\
\text { Constipation } \\
43.1 \% \\
\text { Dysphagia } 27 \% \\
\text { Nausea } 25.7 \% \\
\text { Diarrhea } 13.2 \% \\
\text { Vomiting } 6.9 \%\end{array}$ & $\begin{array}{l}\text { NC group: } \\
\text { 个 MCS } \\
8.1 \\
95 \% \mathrm{Cl} \\
2.3-13.9 \\
\\
\text { PCS } 0.4 \\
95 \% \mathrm{Cl} \\
-5.5-6.4\end{array}$ & $\begin{array}{l}\text { NC group: } \\
\mathrm{HR} 0.57 \\
95 \% \mathrm{Cl} \\
0.35-0.94\end{array}$ \\
\hline $\begin{array}{l}\text { Lim AY, } \\
2015^{25} \\
\text { Korea }\end{array}$ & $\begin{array}{l}\text { Systemic } \\
\text { amyloidosis } \\
\text { with } \\
\text { gastrointestinal } \\
\text { involvement } \\
\text { (AL, AA, ATTR) }\end{array}$ & $\begin{array}{l}\text { Retrospective } \\
\text { cohort }\end{array}$ & $\begin{array}{l}\text { AL } n=20 \\
\text { Age median } \\
56 \\
\text { (range } 37 \text { - } \\
72 \text { ) } \\
\text { Male 55\% }\end{array}$ & $\begin{array}{l}\text { ECOG PS } \geq 2- \\
35 \\
\text { Heart - } 65 \\
\text { PNS - } 31.6 \\
\text { Kidney - } 30 \\
\text { ANS - } 10.5\end{array}$ & NR & $\begin{array}{l}\text { NR } \\
\text { C: any WL } \\
\text { P: } 35 \%\end{array}$ & $\begin{array}{l}\text { Diarrhea } 35 \% \\
\text { Anorexia } 30 \% \\
\text { Gl bleeding } 25 \% \\
\text { Nausea/vomiting } \\
25 \% \\
\text { Constipation } \\
20 \% \\
\text { Dyspepsia 15\% } \\
\text { Reflux } 15 \% \\
\text { Abdominal pain } \\
10 \%\end{array}$ & NR & NR \\
\hline $\begin{array}{l}\text { Said SM, } \\
2015^{26}, \\
\text { USA } \\
\text { Mayo Clinic }\end{array}$ & $\begin{array}{l}\text { Amyloidosis } \\
\text { with } \\
\text { gastrointestinal } \\
\text { involvement } \\
\text { (AA, AL, AApo } \\
\text { A1, ATTR) }\end{array}$ & $\begin{array}{l}\text { Retrospective } \\
\text { cohort }\end{array}$ & $\begin{array}{l}\text { AL } n=53 \\
\text { Age median } \\
61 \text { (range } \\
43-96) \\
\text { Male } 64 \%\end{array}$ & $\begin{array}{l}\text { NR } \\
\text { Heart - } 74 \\
\text { Kidney - } 55 \\
\text { Nerve - } 26 \\
\text { Liver - } 15 \\
\text { Soft } \\
\text { tissue/oral }\end{array}$ & NR & $\begin{array}{l}\text { NR } \\
\text { C: any WL } \\
\text { P: } 34 \%\end{array}$ & $\begin{array}{l}\text { Abdominal pain/ } \\
\text { dyspepsia } 28 \% \\
\text { Nausea/vomiting } \\
23 \% \\
\text { Dysphagia } 23 \% \\
\text { Diarrhea } 8 \% \\
\text { Early satiety } 8 \% \\
\text { Gl bleeding } 6 \%\end{array}$ & NR & NR \\
\hline
\end{tabular}




\begin{tabular}{|c|c|c|c|c|c|c|c|c|c|}
\hline & & & & cavity - 8 & & & Reflux 4\% & & \\
\hline $\begin{array}{l}\text { Caccialanza R, } \\
2014^{17}, \\
\text { Italy }\end{array}$ & $\begin{array}{l}\text { Systemic AL } \\
\text { Amyloidosis, } \\
\text { newly } \\
\text { diagnosed and } \\
\text { treatment- } \\
\text { naïve }\end{array}$ & $\begin{array}{l}\text { Prospective } \\
\text { cohort }\end{array}$ & $\begin{array}{l}\mathrm{n}=128 \\
\text { Age } 63.7 \pm \\
9.9 \\
\text { Male } 59.4 \%\end{array}$ & $\begin{array}{l}\text { ECOG PS } \geq 2- \\
46.9 \\
\text { Heart - } 78.1\end{array}$ & $\begin{array}{l}25.2 \pm 4.0 \\
C:<22 \\
P: 21.9 \%\end{array}$ & $\begin{array}{l}\text { median } 3.0 * \\
\text { (IQR } 0.0- \\
6.0) \\
C 1: \geq 10 \% \\
P 1: 15.6 \%\end{array}$ & NR & NR & $\begin{array}{l}\mathrm{BMI}<22: \\
\mathrm{HR} 1.98 \\
95 \% \mathrm{Cl} \\
1.09-3.56 \\
\mathrm{WL}{ }^{*} \geq 10 \%: \\
\mathrm{HR} 1.94 \\
95 \% \mathrm{Cl} \\
1.00-3.74 \\
\\
\text { Moderate } \\
\text { malnutrition } \\
\mathrm{HR} 3.09 \\
95 \% \mathrm{Cl} \\
1.75-5.46 \\
\text { Severe } \\
\text { malnutrition } \\
\mathrm{HR} 2.88 \\
95 \% \mathrm{Cl} \\
1.23-6.72\end{array}$ \\
\hline $\begin{array}{l}\text { Caccialanza R, } \\
2013^{27} \\
\text { Italy }\end{array}$ & $\begin{array}{l}\text { AL amyloidosis, } \\
\text { newly } \\
\text { diagnosed and } \\
\text { untreated }\end{array}$ & $\begin{array}{l}\text { Prospective } \\
\text { cohort }\end{array}$ & $\begin{array}{l}n=187 \\
\text { Age } 64.3 \pm \\
9.5 \\
\text { Male } 61 \%\end{array}$ & $\begin{array}{l}\text { NR } \\
\text { Heart - } 79.1 \\
\text { Liver - } 17.6\end{array}$ & $24.8 \pm 3.8$ & $\begin{array}{l}5.5 \\
\text { (range 1.6- } \\
10)^{*} \\
C: \geq 10 \% * \\
P: 18.2 \%\end{array}$ & NR & NR & NR \\
\hline $\begin{array}{l}\text { Sattianayagam } \\
\text { PT, } \\
2013^{16} \\
\text { UK }\end{array}$ & $\begin{array}{l}\text { Systemic AL } \\
\text { amyloidosis, } \\
\text { newly } \\
\text { diagnosed and } \\
\text { treatment- } \\
\text { naïve }\end{array}$ & $\begin{array}{l}\text { Prospective } \\
\text { cohort }\end{array}$ & $\begin{array}{l}\mathrm{n}=110 \\
\text { Age median } \\
66 \text { (range } \\
42-88 ; \text { IQR } \\
60,74 \text { ) } \\
\text { Male } 60 \%\end{array}$ & $\begin{array}{l}\text { Mayo disease } \\
\text { stage } \\
\text { I- } 14.5 \\
\text { II- } 31.8 \\
\text { III- } 53.7 \\
\text { Kidney - } 77.3 \\
\text { Heart - } 62.7 \\
\text { Liver - } 14.6 \\
\text { ANS - } 14.6\end{array}$ & $\begin{array}{l}\text { median } 25 \\
\text { (IQR } 23 \text { - } \\
29)\end{array}$ & $\begin{array}{l}\text { NR } \\
\text { C: any WL } \\
P: 60 \% *\end{array}$ & $\begin{array}{l}\text { Reduced } \\
\text { appetite } 43 \% \\
\text { Dysgeusia } 27 \% \\
\text { Early satiety } 25 \%\end{array}$ & $\begin{array}{l}\text { 个 PG- } \\
\text { SGA } \\
\text { scores } \\
\downarrow \text { overall } \\
\text { QoL } \\
(p<0.001)\end{array}$ & $\begin{array}{l}\text { Reference: } \\
\text { Score 0-1 } \\
\text { PG-SGA } \\
\text { score 4-8: } \\
\text { HR } 6.2 \\
95 \% \text { CI } \\
1.2 \text { - } 32.4 \\
\text { PG-SGA }\end{array}$ \\
\hline
\end{tabular}




\begin{tabular}{|c|c|c|c|c|c|c|c|c|c|}
\hline & & & & $\begin{array}{l}\text { PNS - } 9.1 \\
\text { GI - } 4.6\end{array}$ & & & & & $\begin{array}{l}\text { score } \geq 9 \text { : } \\
\text { HR } 6.4 \\
95 \% \mathrm{Cl} \\
1.4-30.2\end{array}$ \\
\hline $\begin{array}{l}\text { Cowan AJ, } \\
2013^{28} \\
\text { USA }\end{array}$ & $\begin{array}{l}\text { Amyloidosis } \\
\text { with GI } \\
\text { involvement } \\
\text { (localized and } \\
\text { systemic AL, } \\
\text { ALys, ATTR, } \\
\text { ATTRw) }\end{array}$ & $\begin{array}{l}\text { Retrospective } \\
\text { cohort }\end{array}$ & $\begin{array}{l}\text { AL } n=50 \\
\text { Systemic } \\
\text { Age median } \\
63 \text { (range } \\
46-79 \text { ) } \\
\text { Male } 64 \%\end{array}$ & $\begin{array}{l}\text { NR } \\
\text { Heart - } 48 \\
\text { Nerves - } 38 \\
\text { Kidney - } 36\end{array}$ & NR & $\begin{array}{l}\text { NR } \\
\text { C: any WL } \\
\text { P: } 58 \%\end{array}$ & $\begin{array}{l}\text { Nausea } 38 \% \\
\text { Constipation } \\
20 \% \\
\text { Diarrhea } 18 \% \\
\text { Anorexia } 14 \% \\
\text { Gl bleeding } 8 \%\end{array}$ & NR & NR \\
\hline $\begin{array}{l}\text { Hernández- } \\
\text { Reyes J, } \\
2012^{29}, \\
\text { Mexico }\end{array}$ & $\begin{array}{l}\text { Systemic AL } \\
\text { amyloidosis }\end{array}$ & $\begin{array}{l}\text { Retrospective } \\
\text { cohort }\end{array}$ & $\begin{array}{l}\mathrm{n}=23 \\
\text { Age median } \\
57 \text { (range } \\
39-98 \text { ) } \\
\text { Male } \\
47.82 \%\end{array}$ & $\begin{array}{l}\text { NR } \\
\text { NR }\end{array}$ & NR & $\begin{array}{l}\text { NR } \\
C:>10 \% \\
P: 6 \%\end{array}$ & NR & NR & NR \\
\hline $\begin{array}{l}\text { Caccialanza R, } \\
2012^{30} \\
\text { Italy }\end{array}$ & $\begin{array}{l}\text { Systemic AL } \\
\text { amyloidosis, } \\
\text { newly } \\
\text { diagnosed }\end{array}$ & $\begin{array}{l}\text { Prospective } \\
\text { cohort }\end{array}$ & $\begin{array}{l}\mathrm{n}=150 \\
\text { Age 65 } \pm 8.9 \\
\text { (range 39- } \\
87 \text { ) } \\
\text { Males } \\
61.3 \%\end{array}$ & $\begin{array}{l}\text { ECOG PS } \geq 3- \\
14 \\
\text { Heart - } 83.3 \\
\text { Kidney }-63.3 \\
\text { Liver }-17.3 \\
\text { GI } 10-6.7\end{array}$ & $\begin{array}{l}24.6 \pm 3.59 \\
C:<22 \\
P: 24.7 \%\end{array}$ & 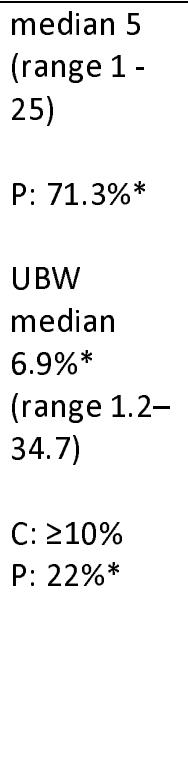 & NR & $\begin{array}{l}\text { WL> 10\% } \\
\downarrow P C S \\
(p<0.001) \\
\downarrow M C S \\
(p=0.003) \\
\text { BMK } 22 \\
\downarrow P C S \\
(0.023) \\
\text { MCS } \\
(0.092) \\
\text { MAMC< } \\
10 \text { th } \\
\text { percentile } \\
\downarrow P C S \\
\text { (0.007) } \\
\text { MCS }\end{array}$ & NR \\
\hline
\end{tabular}




\begin{tabular}{|c|c|c|c|c|c|c|c|c|c|}
\hline & & & & & & & & $(p=0.60)$ & \\
\hline $\begin{array}{l}\text { Madsen LG, } \\
2009^{31}, \\
\text { Denmark }\end{array}$ & $\begin{array}{l}\text { AL amyloidosis } \\
\text { - } \\
\text { with } \\
\text { gastrointestinal } \\
\text { involvement }\end{array}$ & $\begin{array}{l}\text { Retrospective } \\
\text { cohort }\end{array}$ & $\begin{array}{l}\mathrm{n}=11 \\
\text { Age median } \\
60 \text { (range } \\
50-69 \text { ) } \\
\text { Male } 63.6 \%\end{array}$ & $\begin{array}{l}\text { NR } \\
\text { Kidneys - } 72.7 \\
\text { Heart - } 54.5 \\
\text { Bone marrow } \\
-54.5 \\
\text { Liver - } 9 \\
\text { PNS - } 36.7\end{array}$ & NR & $\begin{array}{l}\begin{array}{l}\text { median } 7 \\
\text { (range } 0-25 \text { ) }\end{array} \\
\text { C1: any WL } \\
\text { P1: } 90.9 \% \\
\text { C2: }>10 \mathrm{~kg} \\
\text { P2: } 36 \%\end{array}$ & $\begin{array}{l}\text { Diarrhea } 45.5 \% \\
\text { Reflux } 36.4 \% \\
\text { Constipation } \\
9.1 \% \\
\text { Abdominal pain } \\
9.1 \% \\
\text { Gl bleeding 9.1\% } \\
\text { Fecal fat } 63.6 \%\end{array}$ & NR & NR \\
\hline $\begin{array}{l}\text { Caccialanza R, } \\
2006^{32}, \\
\text { Italy }\end{array}$ & $\begin{array}{l}\text { Systemic AL } \\
\text { amyloidosis }\end{array}$ & $\begin{array}{l}\text { Prospective } \\
\text { cohort }\end{array}$ & $\begin{array}{l}\mathrm{n}=106 \\
\text { Age median } \\
60 \text { (range } \\
28-78 \text { ) } \\
\text { Male } 56.6 \%\end{array}$ & $\begin{array}{l}\text { ECOG PS } \\
0-27.4 \\
1-45.3 \\
2-17.9 \\
3-9.4 \\
\text { Kidney - } 74.5 \\
\text { Heart - } 60 \\
\text { Liver - } 24 \\
\text { GI - } 2.8\end{array}$ & $\begin{array}{l}\text { median } \\
24.5 \\
\text { (rage 17.5- } \\
33.7 \text { ) } \\
\text { C1: BMI<22 } \\
\text { P1: } 23.6 \% \\
\text { C2: } \\
\text { BMI<18.5 } \\
\text { P2: } 2.8 \%\end{array}$ & $\begin{array}{l}\text { median } 8 \\
\text { (range 2- } \\
30 \text { ) } \\
\text { UBW } \\
\text { median } \\
11.3 \% \\
\text { (range } 2.6- \\
34 \%) \\
\text { C: any WL } \\
\text { P: } 54.7 \%\end{array}$ & $\begin{array}{l}\text { Dysgeusia } 34 \% \\
\text { Anorexia } 31.1 \% \\
\text { Vomiting } 17 \% \\
\text { Dysphagia } 14.1 \% \\
\text { Diarrhea } 8.5 \%\end{array}$ & NR & $\begin{array}{l}\text { BMI }<22: \\
\downarrow \text { survival } \\
(P<0.001)\end{array}$ \\
\hline $\begin{array}{l}\text { Gertz MA, } \\
2004^{33}\end{array}$ & $\begin{array}{l}\text { Systemic AL } \\
\text { amyloidosis }\end{array}$ & $\begin{array}{l}\text { Pre and Post } \\
\text { Multicenter } \\
\text { Phase } 2 \text { study }\end{array}$ & $\begin{array}{l}\mathrm{N}=28 \\
\text { Age median } \\
54 \\
\text { (range } 42- \\
71 \text { ) } \\
\text { Male } 71 \%\end{array}$ & $\begin{array}{l}\text { NR } \\
\text { Kidney - } 93 \\
\text { Liver - } 25 \\
\text { Heart - } 25 \\
\text { PNS - } 18\end{array}$ & NR & $\begin{array}{l}\text { NR } \\
\text { C1: <5\%* } \\
\text { P1: } 14 \% \\
\text { C2: } 5-10 \% * \\
\text { P2: } 4 \% \\
\text { C3: }>10 \% * \\
\text { P3: } 7 \%\end{array}$ & NR & NR & NR \\
\hline
\end{tabular}




\begin{tabular}{|c|c|c|c|c|c|c|c|c|c|}
\hline $\begin{array}{l}\text { Park, MA, } \\
2003^{34}, \\
\text { USA } \\
\text { Mayo Clinic }\end{array}$ & $\begin{array}{l}\text { Systemic AL } \\
\text { amyloidosis } \\
\text { with liver } \\
\text { involvement }\end{array}$ & $\begin{array}{l}\text { Retrospective } \\
\text { cohort }\end{array}$ & $\begin{array}{l}\mathrm{n}=98 \\
\text { Age median } \\
58.5 \\
\text { Male } 69 \%\end{array}$ & $\begin{array}{l}\text { NR } \\
\text { Kidney - } 33 \\
\text { Heart - } 12 \\
\text { PNS - } 6\end{array}$ & NR & $\begin{array}{l}10.4 \\
\text { C: any WL } \\
\text { P: } 72 \%\end{array}$ & $\begin{array}{l}\text { Abdominal pain } \\
53 \% \\
\text { Anorexia } 26 \% \\
\text { Early satiety } 19 \% \\
\text { Nausea } 15 \% \\
\text { Dysgeusia } 10 \%\end{array}$ & NR & NR \\
\hline $\begin{array}{l}\text { Hayman SR, } \\
2001^{35}, \\
\text { USA } \\
\text { Mayo Clinic }\end{array}$ & $\begin{array}{l}\text { Systemic AL } \\
\text { amyloidosis } \\
\text { with } \\
\text { malabsorption } \\
\text { syndrome }\end{array}$ & $\begin{array}{l}\text { Retrospective } \\
\text { cohort }\end{array}$ & $\begin{array}{l}\mathrm{n}=19 \\
\text { Age median } \\
63 \text { (range } \\
41-74 \text { ) } \\
\text { Male } 74 \%\end{array}$ & $\begin{array}{l}\text { NR } \\
\text { Heart - } 77 \\
\text { Bone marrow } \\
-36\end{array}$ & NR & $\begin{array}{l}\text { median } 30 \\
\text { (range 2- } \\
\text { 134) } \\
\text { C1: any WL } \\
\text { P1: } 100 \% \\
\text { C2: >20lb } \\
\text { P2: } 68.4 \%\end{array}$ & $\begin{array}{l}\text { Diarrhea } 68.4 \% \\
\text { Anorexia } 42.1 \% \\
\text { Steatorrhea, } \\
\text { nausea, or } \\
\text { Abdominal pain } \\
26.31 \% \\
\text { Vomiting or } \\
\text { edema } 21 \%\end{array}$ & NR & $\begin{array}{l}\text { WL } \leq 20 \mathrm{lb}: \\
\text { median } \\
\text { survival - } 22 \\
\text { months } \\
\text { WL >20 lb: } \\
\text { median } \\
\text { survival - } 10 \\
\text { months }\end{array}$ \\
\hline $\begin{array}{l}\text { Dispenzieri A, } \\
2001^{36} \\
\text { USA } \\
\text { Mayo Clinic }\end{array}$ & $\begin{array}{l}\text { Systemic AL } \\
\text { amyloidosis }\end{array}$ & $\begin{array}{l}\text { Retrospective } \\
\text { cohort }\end{array}$ & $\begin{array}{l}\mathrm{n}=229 \\
\text { Age median } \\
56 \\
\text { (range } 25 \text { - } \\
70 \text { ) } \\
\text { Male } 58 \%\end{array}$ & $\begin{array}{l}\text { ECOG PS } \\
0-40 \\
1-41 \\
2-12 \\
3-5 \\
\text { Kidney - } 73 \\
\text { Heart - } 44 \\
\text { Liver - } 18 \\
\text { Nerve - } 17 \\
\text { GI - } 3.9 \\
\text { Lung - } 1.31\end{array}$ & NR & $\begin{array}{l}\text { NR } \\
\text { C1: } \leq 10 \mathrm{lb} \\
\mathrm{P} 1: 60.3 \% \\
\mathrm{C} 2:>10 \mathrm{lb} \\
\mathrm{P} 2: 39.7 \%\end{array}$ & NR & NR & $\begin{array}{l}\text { WL }>10 \mathrm{lb} \\
\downarrow \text { survival } \\
\text { RR } 1.5 \\
95 \% \mathrm{Cl} \\
1.1-2.1\end{array}$ \\
\hline $\begin{array}{l}\text { Dubrey SW, } \\
1998^{37}, \\
\text { USA }\end{array}$ & $\begin{array}{l}\text { AL amyloidosis } \\
\text { with heart } \\
\text { involvement }\end{array}$ & $\begin{array}{l}\text { Retrospective } \\
\text { cohort }\end{array}$ & $\begin{array}{l}n=232 \\
\text { Age } 60 \pm 11 \\
\text { median } 59 \\
\text { (range } 29- \\
85 \text { ) } \\
\text { Male } 61 \%\end{array}$ & $\begin{array}{l}\text { NR } \\
\text { Heart - } 100 \\
\text { GI - } 68 \\
\text { Kidney - } 67 \\
\text { Nervous } \\
\text { System - } 55 \\
\text { Musculo- }\end{array}$ & NR & $\begin{array}{l}\text { NR } \\
\text { C1: } \geq 10 \mathrm{lb} \\
\text { P1: } 42.7 \% \\
\text { C2: } 10-20 \mathrm{lb} \\
\text { P2: } 18.1 \%\end{array}$ & $\begin{array}{l}\text { Early satiety/ } \\
\text { anorexia } 22.8 \% \\
\text { Nausea } 22.8 \% \\
\text { Dysphagia } 6 \% \\
\text { Diarrhea } 29.3 \% \\
\text { Dysgeusia } 10.3 \% \\
\text { Constipation } \\
6.0 \%\end{array}$ & NR & NR \\
\hline
\end{tabular}




\begin{tabular}{|c|c|c|c|c|c|c|c|c|c|}
\hline & & & & $\begin{array}{l}\text { Skeletal - } 31 \\
\text { Skin - } 25 \\
\text { Lung - } 16\end{array}$ & & $\begin{array}{l}\text { C3: } 21-30 \mathrm{lb} \\
\text { P3: } 12.9 \% \\
\text { C4: } 31-40 \mathrm{lb} \\
\text { P4: } 4.3 \% \\
\text { C5: >50lb } \\
\text { P5: } 7.3 \%\end{array}$ & $\begin{array}{l}\text { Abdominal } \\
\text { discomfort } \\
10.8 \%\end{array}$ & & \\
\hline $\begin{array}{l}\text { Kyle RA, } \\
1995^{38} \\
\text { USA } \\
\text { Mayo Clinic }\end{array}$ & $\begin{array}{l}\text { Systemic AL } \\
\text { amyloidosis }\end{array}$ & $\begin{array}{l}\text { Retrospective } \\
\text { cohort }\end{array}$ & $\begin{array}{l}\mathrm{n}=474 \\
\text { Age median } \\
64 \text { (range } \\
32-90 \text { ) } \\
\text { Male } 69 \%\end{array}$ & $\begin{array}{l}\text { NR } \\
\text { Kidney - } 30 \\
\text { Heart - } 22 \\
\text { PNS - } 17\end{array}$ & NR & $\begin{array}{l}\text { median 23lb } \\
\text { (range 4- } \\
200 \text { ) } \\
\text { C: any WL } \\
\text { P: } 52 \%\end{array}$ & NR & NR & NR \\
\hline $\begin{array}{l}\text { Menke, DM, } \\
1993^{39} \\
\text { USA } \\
\text { Mayo Clinic }\end{array}$ & $\begin{array}{l}\text { Systemic AL } \\
\text { amyloidosis } \\
\text { with } \\
\text { Symptomatic } \\
\text { Gastric } \\
\text { Amyloidosis }\end{array}$ & $\begin{array}{l}\text { Retrospective } \\
\text { cohort }\end{array}$ & $\begin{array}{l}\mathrm{n}=8 \\
\mathrm{NR} \\
\mathrm{NR}\end{array}$ & $\begin{array}{l}\text { NR } \\
\text { NR }\end{array}$ & NR & $\begin{array}{l}\text { (range 6.5- } \\
22.5) \\
\text { C: any WL } \\
\text { P: } 87.5 \%\end{array}$ & $\begin{array}{l}\text { Hematemesis or } \\
\text { prolonged } \\
\text { nausea and } \\
\text { vomiting } 100 \%\end{array}$ & NR & NR \\
\hline
\end{tabular}

* Within the past 6 months; ** data provided by the author; BMI - body mass index: values are mean \pm standard deviation; WL - weight loss: values are mean \pm standard deviation; MAMC - mid-arm muscle circumference; QoL - Quality of life; SD - standard deviations; IQR - interquartile range; C - criteria; P -

prevalence; NR - not reported; ECOG PS - Eastern Cooperative Oncology Group performance status; GI - gastrointestinal; MCS - mental component summary; NC - nutritional counseling; PG-SGA score - Patient-Generated Subjective Global Assessment; PNS - peripheral nervous system; UBW - usual body weight; UC usual care; AA - Secondary amyloidosis (associated with deposition of serum amyloid A protein); AApo A1 - apolipoprotein A1 amyloidosis; AL -

immunoglobulin light chain amyloidosis; ALys - Hereditary lysozyme (ALys) amyloidosis; ANS - Autonomic nervous system; ATTR- amyloidosis transthyretinrelated; ATTRwt - transthyretin wild-type; ATTRv - transthyretin mutant form; LCDD light - chain deposition disease; MAMC - mid-arm muscle circumference; MCN - myeloma cast nephropathy; 
Table 2. Cut-off point variation of malnutrition parameters, and agreement with GLIM criteria.

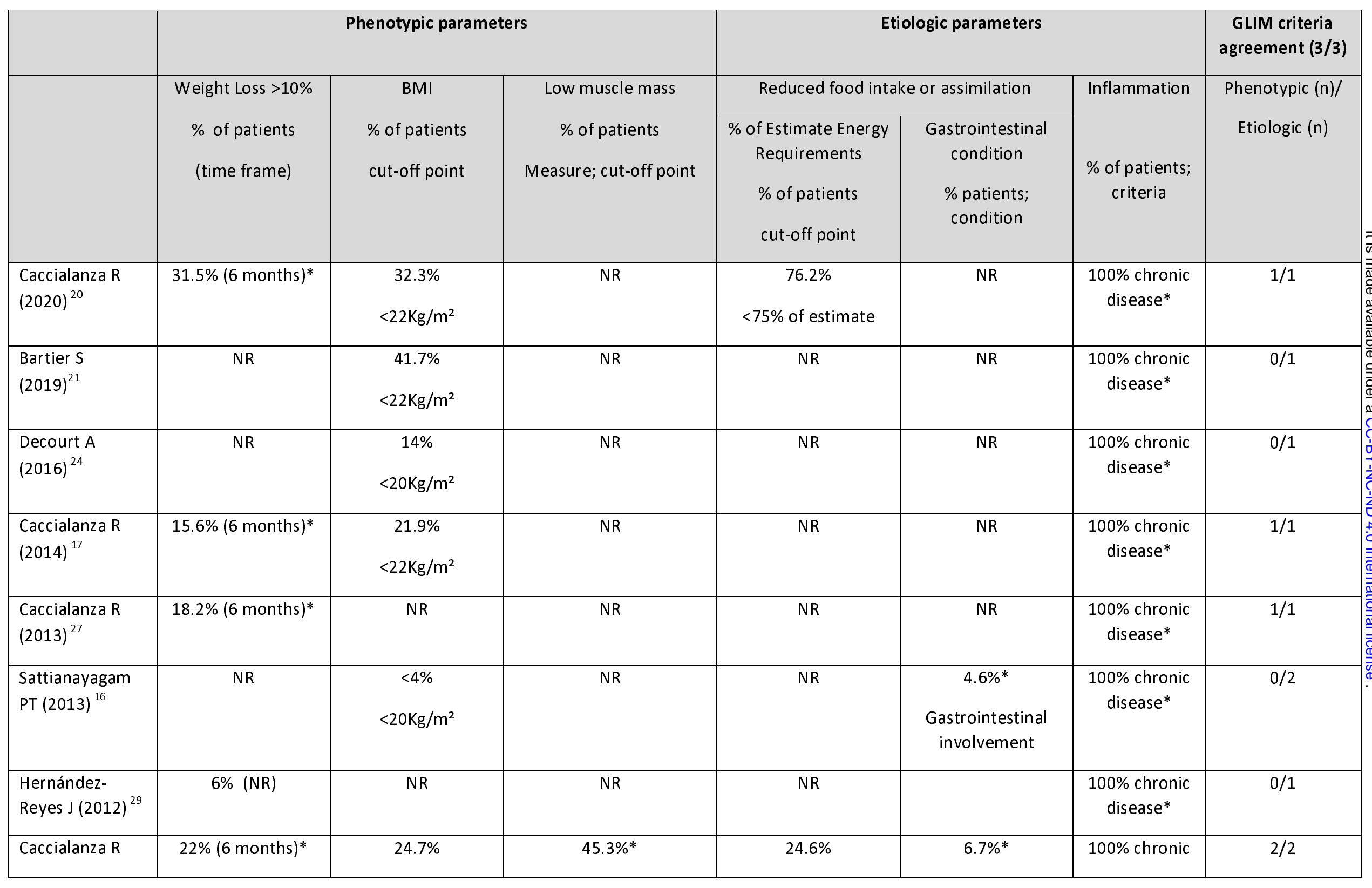




\begin{tabular}{|c|c|c|c|c|c|c|c|}
\hline$(2012)^{30}$ & & $<22 \mathrm{Kg} / \mathrm{m}^{2}$ & MAMC $<10^{\text {th }}$ percentile & $<60 \%$ of estimate & $\begin{array}{c}\text { Gastrointestinal } \\
\text { involvement }\end{array}$ & disease* & \\
\hline $\begin{array}{l}\text { Caccialanza R } \\
(2006)^{32}\end{array}$ & NR & $\begin{array}{l}23.6 \%<22 \mathrm{Kg} / \mathrm{m}^{2} \\
2.8 \%<18.5 \mathrm{Kg} / \mathrm{m}^{2}\end{array}$ & $\begin{array}{c}27.3 \% * \\
\text { MAMC }<10^{\text {th }} \text { percentile }\end{array}$ & NR & $\begin{array}{l}\text { 34\% Dysgeusia } \\
\text { 31.1\% Anorexia } \\
\text { 17\% Vomiting } \\
\text { 14.1\% Dysphagia } \\
\text { 8.5\% Diarrhea* }\end{array}$ & $\begin{array}{c}100 \% \text { chronic } \\
\text { disease* }\end{array}$ & $1 / 2$ \\
\hline $\begin{array}{l}\text { Gertz MA } \\
(2004)^{33}\end{array}$ & $7 \%$ (6 months) $^{*}$ & NR & NR & NR & NR & $\begin{array}{c}100 \% \text { chronic } \\
\text { disease* }\end{array}$ & $1 / 1$ \\
\hline
\end{tabular}

NR: Not Reported.*Assessment parameter and cut-off point completely in accordance with GLIM criteria. 

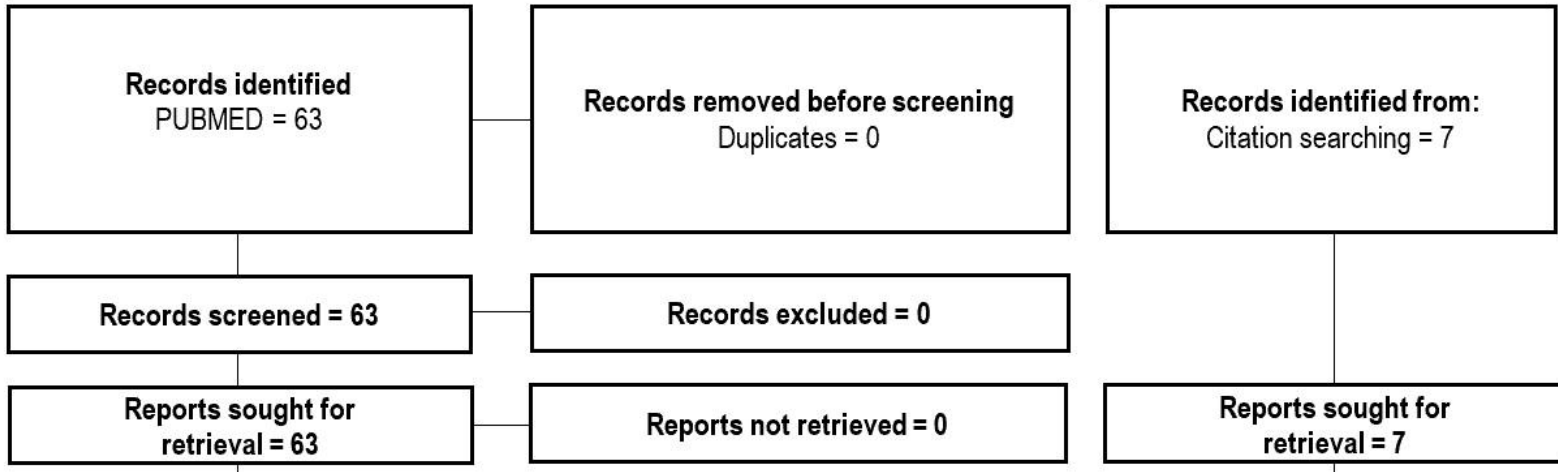

\section{Records excluded $=0$}

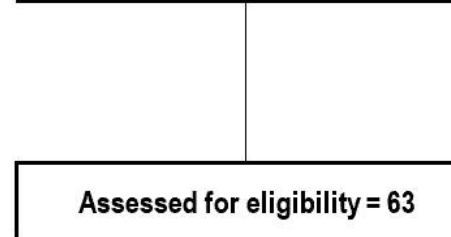

Reports not retrieved $=0$

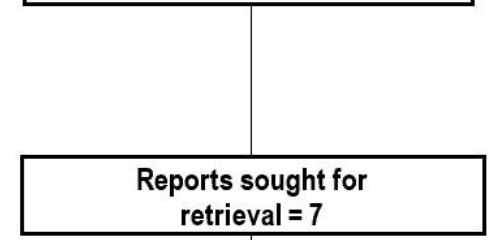

Excluded $=\mathbf{4 7}$

Population $=3$

Animal studies $=1$

Case-reports $=34$

$$
\text { Reviews }=3
$$

No data on outcome of interest $=6$

Assessed for eligibility $=7$

\begin{tabular}{|l|c|c|}
\hline \multicolumn{2}{|c|}{ Included in the report } \\
Full text & Abstract $\quad$ All \\
$\mathrm{k}=23$ & $\mathrm{k}=0$ & $\mathrm{k}=23$ \\
& \\
Studies that presented any GLIM criteria $\mathrm{K}=10$ \\
Studies that described malnutrition $\mathrm{K}=4$
\end{tabular}


medRxiv preprint doi: https://doi.org/10.1101/2021.04.14.21255509; this version posted April 20, 2021. The copyright holder for this preprint (which was not certified by peer review) is the author/funder, who has granted medRxiv a license to display the preprint in perpetuity.

It is made available under a CC-BY-NC-ND 4.0 International license .

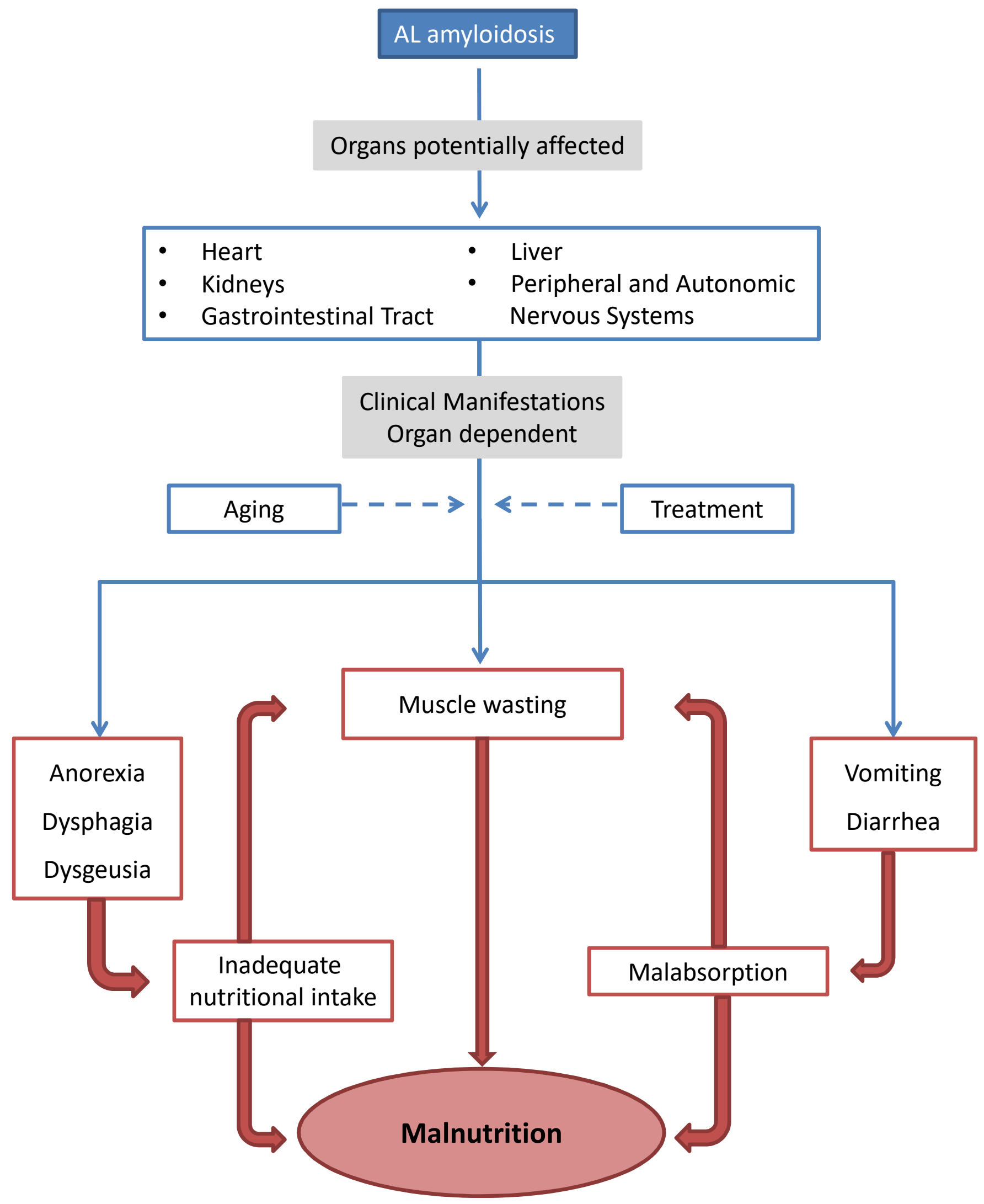

